\title{
ERROR ANALYSIS OF CONDITIONAL SENTENCES
}

\author{
WILNA KRISTINA, ALBERT RUFINUS, MASFA MAIZA \\ Pamane Talino College of Education \\ wilnakristina13@gmail.com \\ Pamane Talino College of Education \\ rufinusledjo@gmail.com \\ Pamane Talino College of Education \\ masfamaiza27@gmail.com
}

First Received: 29-02-2020; Accepted: 05-03-2020

\begin{abstract}
Making mistakes when using conditional sentences is common for foreign language learners. Errors in this study are in accordance with the error classification surface strategy taxonomy, namely omission, addition, misformation and misordering. The purposes of this study are to identify and to classify the types of error and to find the factors causing errors in the use of conditional sentences. The research method used is descriptive qualitative research method that is a case study with taxonomic analysis. Data collection techniques were carried out using test and interview. The research subject was third semester students of the English Language Education Study Program 2018/2019 of Pamane Talino College of Education in Landak Regency, West Kalimantan. The results show that $30.27 \%$ of students make omission errors, $21.11 \%$ addition errors, $34.86 \%$ misformation errors and $13.76 \%$ misordering errors. The factors that cause errors are found from the system's own target language (intralingual). The main error factors classified as intralingual errors in this study are: incomplete knowledge in verb forms, incomplete application of rules and false concept hypothesis.
\end{abstract}

Keywords: error, conditional sentences

\section{INTRODUCTION}

Grammar in English has a different form, so learners need to pay attention to this more closely in order to speak English properly and correctly. One small unit in grammar is conditional sentences. Conditional sentences are sentences that usually start with "if" where one part of the sentence depends on another part. Someone tells a conditional sentence when supposing something that does not necessarily happen or even does not happen. The structure of the conditional sentences consists of two, namely in the form of the main sentence (main clause) and clause (sub clause or if clause), (Pare, 2018).

In conditional sentences, things to consider when studying this section are the use of verbs, pronouns, tenses and to be. The process of lectures on Complex English Grammar is still not running optimally due to several factors such as those obtained by the researcher in an interview with the lecturer who is in charge of the Complex English Grammar course. 
Based on interview conducted by researcher with lecturer in the Complex English Grammar course and several third semester students of English language education study program on November $7^{\text {th }}, 2018$, it found that students had difficulty in changing basic verbs (infinitives) into second form verbs (past tense) and third form of the verb (past participle).

Then, students also have difficulty in determining verbs (verbs) that correspond to pronouns (pronouns). Students often make these mistakes because of confusion due to the influence of mother tongue that does not have the same linguistic structure; hence students have difficulty in determining verbs (verbs) that correspond to pronouns (pronouns). This is proven by the erroneous work of students that the results achieved are not in accordance with the expected results. In addition, students' learning and reading motivation is also lacking, so they are confused when learning grammar in the classroom because they only expect lecturers to tell.

Then, from interview with a number of third semester students, they generally stated that the Complex English Grammar course was a subject that was very difficult to understand because it had various rules, patterns and formulas that were difficult to remember. In learning grammar, students still have not mastered some parts of speech such as verbs and pronouns. Students tend to be passive when in class because they are confused by the material presented. Therefore, some students are not interested in learning this course. Regarding to the problems above, the purposes of this study are:

1. To identify and classify the types of errors made by students in the use of conditional sentences.

2. To identify the factors causing students to make mistakes in the use of conditional sentences.

\section{Language Errors}

Language errors are things that are often done in the process of learning the target language. This happens because speakers have not fully mastered the rules of the language being studied, so it needs to be studied in order to obtain solutions to overcome this. According to Dulay, Burt and Krashen in Anjasari, Suwandi and Mulyono (2013) said that "error is a part of a conversation that deviates from some selected norms of nature language performance". 
Parrera in Johan and Simatupang (2017) states that in general language errors are divided into two, namely language errors (errors) and language errors (mistakes). Corder in Latif (2015) also argues that there is a difference between mistakes and errors because the terms of the term are technically very different. Mistakes (mistakes) the same as errors that are not systematic or mistakes that occur because it is influenced by performance factors (performance) such as forgetfulness, fatigue, drowsiness, sprains (tongue) and others. Error (error) is a systematic error caused by ability factors such as low / minimal knowledge of the rules of the language of the target language or because the learner is still in the process of developing or still increasing knowledge of the rules of the second language.

From the above opinion it can be clearly seen the difference between language errors (errors) and language errors (mistakes), namely errors (errors) occur systematically in which learners make mistakes related to the rules of language. This shows the learner's inability to master the grammar of the target language. Meanwhile, mistakes (mistakes) occur unsystematically due to performance factors such as fatigue, sprain of the tongue, drowsiness and others.

Language errors need to be studied or analysed to determine the level of difficulty experienced by learners in the learning process of the target language so that it can be overcome with the results of the analysis that will make the teacher more focused on the mistakes made so they don't happen again. Error analysis (error analysis) according to Stern in Latif (2015), error analysis is a learning technique for learning the forms of difficulties in second language learning.

According to Khodabaeh in Munadzdzofah and Sudomo (2016), the main causes of errors are as follows:

1. Interlingual (Transfer Errors)

Corder in Munadzdzofah and Sudomo (2016) states that this error is associated with native language (Native Language). This error occurs when the habits of first language learners (L1) are in the form of patterns, systems or rules that disturb them to some extent, from obtaining patterns and rules of second language. 
2. Interference (Negative Transfer)

Lado in Munadzdzofah and Sudomo (2016) suggested that interference is a negative influence of mother tongue (L1) on the performance of the target language or target language students. For example, the wording of the Indonesian word is contrary to the English order system.

3. Intralingual (Developmental Errors)

According to Richards in Munadzdzofah and Sudomo (2016), this error is something produced by students that reflects not derived from the structure of the mother tongue, but generalization based on partial exposure because students do not understand the existing language rules so that students generalize all language rules he knows, in other words students only guess to solve the problems that have been given.

James in Suhono (2016) states that the learners' error version is different from the presumed target version. This highlights the ways surface structures are altered. The mistakes made by learners are different from the expected language learning target so it is necessary to identify what mistakes are often made. Therefore, one of the strategies used to identify these errors is the classification of surface strategies (surface strategy taxonomy).

Then Tarigan and Tarigan (2011) classify the types of errors based on the Surface Strategy Taxonomy Classification into four categories, namely: omission, addition error, misformation and misordering). Omission is characterized by the absence of something that should be in good and right speech. Addition is a category of errors in which learners add items that are not needed in a word. Misformation is a category of errors that is marked by the use of morphemes or incorrect structures. Misordering is an error marked by the placement of an incorrect morpheme or group of morphemes.

\section{Conditional Sentences}

According to Nurholis (2009), conditional sentences are conditional sentences or conditional sentences consisting of two parts, namely If Clause (clause, which contains terms) and Main Clause (main sentence, which contains consequences). In English, presuppositions are divided into 3 types: Type 1 . Future possible; type 2. Present unreal and type 3 . Past unreal. 


\section{METHOD}

This research was conducted at STKIP Pamane Talino Ngabang which is located on Jl. Afandi Rani Ngabang District, Landak Regency, West Kalimantan. This research was qualitative research. According to Azwar in Mahmud (2011), qualitative research is research that emphasizes more on the analysis of deductive and inductive inference processes and on the analysis of the dynamics of the relationship between observed phenomena, using scientific logic.

The data was obtained through interviews and written tests in the form of translating presuppositions in Indonesian into English, arranging random sentences in paragraphs and making conditional sentences sentences freely. The data source in this study is the 7 th semester students of STKIP Pamane Talino Ngabang, amounting to 7 people, consisting of 6 female students and 1 male student.

In order to collect data in this research, the authors use several techniques, namely: interviews and tests. The following is an explanation of the three techniques.

1. Interview

According to Indrawan and Yaniawati (2017, p. 136), interviews in qualitative research is an activity carried out to obtain information directly by asking questions to informants (key informants or informants) to obtain in-depth information. This interview was conducted as a first step in the preparation of the research background and was used as primary data support in the form of a written test given to students. This interview was conducted to find the factors causing students to make mistakes in the use of conditional sentences.

2. Test

Mahmud (2011, p. 185) explains that tests are a series of questions or tools used to measure the skills, knowledge, intelligence, abilities or talents possessed by individuals or groups. The test will be given in the form of a written test in which students are asked to translate a number of sentence sentences in Indonesian in English then arrange random sentences in a prepared text and make conditional sentences with their own sentences. 
According to Raco (2010) Data analysis means systematically arranging the results of interviews and observations, interpreting them and producing a new thought, opinion, theory or idea. Data analysis in research conducted by researchers uses a Surface Strategy Taxonomy analysis to identify errors that are often made by students in using conditional sentences.

The research procedure is a series of activities carried out by the researcher systematically to achieve the objectives of the study. The procedures in this study are: planning, preparing, and implementing.

\section{FINDINGS AND DISCUSSION}

The following are the results of data collection that have been carried out, namely:

\section{Analysis of Error Types}

Researchers have given written tests on conditional sentences to 7 semester III students of the English Education Study Program STKIP Pamane Talino Academic Year 2018/2019 Landak Regency on May 29 ${ }^{\text {th }}, 2019$.

This test consists of 25 written questions, 15 items translate conditional sentences into English. Numbers 1-5 translate conditional sentences: type I (conditional sentences: type I), numbers 6-10 translate conditional sentences: type II (conditional sentences: type II) and numbers 11-15 translate conditional sentences: type III (conditional sentences: type III). 6 items make up random conditional sentences in a text. Numbers 16-18 construct random presupposition sentences: type III (rumble conditional sentences: type III), numbers 19 and 21 compile random presupposition sentences: type I (rumble conditional sentences: type I) and number 18 compile random presupposition sentences: type II (conditional sentences: type II). Then, 4 items create conditional sentences (conditional sentences) freely and independently, with the provisions of making conditional sentences (conditional sentences) type I as many as 2 questions, type II as much as 1 question and type III as much as 1 question.

Table 1 Error Category Frequency

\begin{tabular}{llcc}
\hline No & \multicolumn{1}{c}{ Error Category } & $\begin{array}{c}\text { Number of Error } \\
\text { Categories }\end{array}$ & $\begin{array}{c}\text { Error Category } \\
\text { Frequency }\end{array}$ \\
1 & Omission & 33 & $30,27 \%$ \\
2 & Addition & 23 & $21,11 \%$ \\
3 & Misformation & 38 & $34,86 \%$ \\
4 & Misordering & 15 & $13,76 \%$ \\
& Total & $\mathbf{1 0 9}$ & $\mathbf{1 0 0 \%}$ \\
\hline \multicolumn{4}{c}{40}
\end{tabular}




\section{Factors that Cause Errors}

The interviews provided aim to support existing data. The researcher conducted an interview to the lecturer who taught the Complex English Grammar course especially for Conditional Sentences on Monday, June $17^{\text {th }}, 2019$. The researcher asked ten questions from the lecturer.

Based on the test results and supported by interviews conducted by researchers with lecturers and seven students, the researchers found that the factors causing the error originated from the target language system itself (intralingual) which leads to the complexity of the target language rules being studied. The following are some of the main factors causing errors that are classified as intralingual errors in this research, namely: incomplete knowledge of verb forms, incomplete application of rules and incomplete application hypothesis (false concept hypothesis).

\section{CONCLUSION}

This study concludes that there are 109 total errors in which 33 or $30.27 \%$ errors in the omission, 23 or $21.11 \%$ errors in the addition, 38 or $34.86 \%$ errors in the misformation and 15 or $13.76 \%$ errors in the misordering. The dominant error is misformation. Besides, the factors that cause the error come from the target language system itself (intralingual) which leads to the complexity of the target language rules being studied. The followings are some of the main factors causing errors that are classified as intralingual errors in this study, namely: incomplete knowledge of verb forms because students do not yet have extensive knowledge about the form of verbs, incomplete application of the rules (incomplete application of rules) because of the inability of students to apply the rules of the target language in full and finally the false concept hypothesis because students do not fully understand the rules of the target language being studied. In addition, the following are some suggestions for lecturers and students:

1. Before explaining the subject matter, the lecturer must explain the supporting material needed by students in studying conditional sentences. First, the lecturer must explain supporting material such as tenses, to be, regular and irregular verbs, pronouns, articles and prepositions,

2. Lecturers must become facilitators for students in learning conditional sentences, 
3. Lecturers must also provide reinforcement to students to use conditional sentences,

4. Students must actively ask if there are unclear conditional sentences so they are not confused and feel bored because they do not know,

5. Students must be willing to study independently and read material conditional sentences independently.

\section{REFERENCES}

Anjarsari, N. S. Analisis Kesalahan Pemakaian Bahasa Indonesia Dalam Karangan Mahasiswa Penutur Bahasa Asing Di Universitas Sebelas Maret. Jurnal Penelitian Bahasa, Sastra Indonesia dan Pengajarannya (April 2013), 1-11.

Indrawan Rully \& Yaniawati Poppy. (2017). Metodologi Penelitian. Bandung: PT Refika Aditama.

Johan, Gio Mohamad \& Simatupang, Yusrawati JR. Analisis Kesalahan Berbahasa Indonesia Secara Sintaktis Dalam Proses Diskusi Kelas IV SDN Miri . Jurnal Visipena (Desember 2017), 241-253.

Latif, S. Analisis Kesalahan Mahasiswa Semester II Program Studi Pendidikan Bahasa Inggris Dalam Menggunakan Kata Kerja Bantu Dalam Menulis Di Universitas Khairun. Jurnal Pendidikan (Januari 2015), 224-243.

Mahmud, H. (2010). Metode Penelitian Pendidikan. Bandung: Pustaka Setia.

Munadzdzofah, O. \&. Sudomo, Asmara. Kesalahan Gramatika Terhadap Mata Kuliah Korespondensi Niaga Bahasa Inggris. Jurnal Administrasi Kantor (Juni 2016), 172197.

Nurholis. (2009). Mastering English . Bandung: CV Pustaka Setia.

Pare, F. A. (2018). Master English Course: Grammar Vocabulary Conversation. Yogyakarta: Andaliman Books.

Raco, J. R. (2010). Metode Penelitian Kualitatif Jenis, Karakteristik Dan Keunggulannya. Jakarta: PT Gramedia Widiasarana Indonesia.

Suhono. Surface Strategy Taxonomy On The EFL Students' Composition: A Study Of Error Analysis. Jurnal Edukasi (November 2016), 1-27.

Tarigan, Henry Guntur \& Tarigan, Djago. (2011). Pengajaran Analisis Kesalahan Berbahasa. Bandung: Percetakan Angkasa. 